Acta Cryst. (1984). C40, 465-467

\title{
The Structure of 5-Amino-4-methyl-1-isoquinolinecarbaldehyde Thiosemicarbazone Hydrochloride, $\mathrm{C}_{12} \mathrm{H}_{14} \mathrm{~N}_{3} \mathrm{~S}^{+} . \mathrm{Cl}^{-}$
}

\author{
BY R. KURODA* AND STEPHEN NEIDLE \\ Cancer Research Campaign Biomolecular Structure Research Group, Department of Biophysics, King's College, \\ 26-29 Drury Lane, London WC2B 5RL, England \\ AND D. E. V. WILMAN \\ Department of Biochemical Pharmacology, Cancer Research Campaign Laboratory, Institute of Cancer \\ Research, Clifton Avenue, Sutton, Surrey SM2 5PX, England
}

(Received 14 October 1983; accepted 21 November 1983)

\begin{abstract}
M_{r}=295.80, \quad P 2_{1} / n, \quad a=8.284(1), \quad b=$ $13.906(1), \quad c=12.040$ (2) $\AA, \quad \beta=92.95(1)^{\circ}, \quad V=$ $1385.0(5) \AA^{3}, Z=4, D_{m}=1.42, D_{x}=1.418 \mathrm{Mg} \mathrm{m}^{-3}$, $\lambda(\mathrm{Cu} K \alpha)=1.54178 \AA, \mu=3.8134 \mathrm{~mm}^{-1}, \quad F(000)=$ $616, R=0.061$ for 628 unique significant reflections measured at $298 \mathrm{~K}$. The structure was compared with that of other active/inactive thiosemicarbazone derivatives, in the search for a structure-activity relationship. It was also compared with the structure of a related metal complex.
\end{abstract}

Introduction. Some $\alpha$-(N)-heterocyclic carbaldehyde thiosemicarbazones possess antitumour activity against a wide variety of transplanted tumours (Agrawal \& Sartorelli, 1975) and the activity is related to their inhibitory potency for an enzyme ribonucleoside diphosphate reductase, RDR (French, Blanz, Shaddix \& Brockman, 1974). Kinetic data support an inhibitory mechanism in which either a preformed $\mathrm{Fe}$ chelate of the molecule interacts with the target enzyme or the ligand itself coordinates to the Fe-charged enzyme (Sartorelli, Agrawal \& Moore, 1971). Rational design of thiosemicarbazone derivatives has been explored (Agrawal, Booth, DeNuzzo \& Sartorelli, 1976) in an attempt to obtain high affinity for the target enzyme RDR, high water solubility for easy administration to patients and insensitivity to $O$-glucuronidation. 5Amino-1-isoquinolinecarbaldehyde thiosemicarbazone $\left(5-\mathrm{NH}_{2}\right.$ IQ) was reported to be about 100 times more potent than 5-hydroxy-2-isoquinolinecarbaldehyde thiosemicarbazone as an inhibitor to RDR and to be not susceptible to $O$-glucuronidation (Mooney, Booth, Moore, Agrawal \& Sartorelli, 1974). However, the 5 -amino group is susceptible to $N$-acetylation, a relatively ubiquitous metabolic reaction in vivo. Since the product of $\mathrm{N}$-acetylation, 5 -acetylamino IQ, is completely devoid of carcinostatic activity, Agrawal et

\footnotetext{
* To whom correspondence should be addressed.
}

0108-2701/84/030465-03\$01.50 al. synthesized (Agrawal, Mooney \& Sartorelli, 1976) 5-amino-4-methyl-1-isoquinolinecarbaldehyde thiosemicarbazone (MAIQ) in order to protect the 5-amino group from acetylation, by a bulky methyl group. Acetylation of 5-amino-1,4-dimethylisoquinoline was about 20 times less than 5-amino-1-methylisoquinoline in vitro employing a rat-liver homogenate with labelled acetyl coenzyme A as the substrate (Agrawal, Mooney, Schenkman, Denk, Moore \& Sartorelli, 1975). IQ, $5-\mathrm{NH}_{2}$ IQ, and MAIQ were found to be effective antitumour agents in mice bearing the sarcoma 180 ascites tumour. At the maximum effective daily dose the average survival of animals increased threefold over untreated tumour-bearing controls. As part of our studies of the relationship between detailed molecular structure, ribonucleotide reductase inhibition and subsequent antitumour activity (Cutbush, Neidle \& Wilman, 1983), we have determined the crystal and molecular structure of MAIQ and compared this with those of other active/inactive thiosemicarbazones and of $\mathrm{Ni}^{\mathrm{II}}(\mathrm{IQ})_{2}$.

Experimental. Thin needle-like crystal of dimensions $0.06 \times 0.07 \times 0.39 \mathrm{~mm}$, density measured by flotation, crystal class from X-ray photographs, accurate cell dimensions by least-squares analysis of $25 \theta$ values measured on an Enraf-Nonius CAD-4 diffractometer, intensity data collected with Ni-filtered $\mathrm{Cu} K \alpha$ radiation, $\omega-2 \theta$ scan mode, $\theta_{\max }=50^{\circ}(0 \leq h \leq 8$, $0 \leq k \leq 13,-11 \leq l \leq 11$ ); three standard reflections monitored at intervals of $3600 \mathrm{~s}$ indicated no crystal decay; 1418 unique reflections, 628 of which with $I \geq 1.5 \sigma(I)$ were used for the refinement. Direct methods [MULTAN80 (Main et al., 1980)], refinement on $F$ by full-matrix least squares with anisotropic thermal factors; all the $\mathrm{H}$ atoms but those bonded to $\mathrm{N}(1)$ located from difference Fourier syntheses and included with fixed isotropic thermal and positional parameters; final difference-map peaks $<0.30 \mathrm{e} \AA^{-3}$, (c) 1984 International Union of Crystallography 
unit weights, final $R=0.061,(\Delta / \sigma)_{\max }=0.01$; empirical absorption (program by Walker \& Stuart, 1983) and extinction corrections applied, atomic scattering factors from International Tables for X-ray Crystallography (1974), all computations performed on a PDP $11 / 34$ A computer using the $S D P$ program system (Frenz, 1980).

Discussion. Final atomic parameters are listed in Table $1,{ }^{*}$ Fig. 1 shows a plan and a side view of the molecule with the numbering scheme involved. Table 2 lists bond lengths and angles. $N(3)-N(4)$ of 1.36 (1) $\AA$ is significantly shorter than a normal $\mathrm{N}-\mathrm{N}$ bond. Short $\mathrm{N}-\mathrm{N}$ lengths are also found in other thiosemicarbazones and these contrast with $1.398(6) \AA$ in acetone thiosemicarbazone (ATSC) (Table 3, deposited). $\uparrow$ The shortening of the $\mathrm{N}-\mathrm{N}$ bond can be explained by an extended delocalization involving not only the thiosemicarbazone chain but also aromatic heterocyclic rings, which is not present in ATSC. The short C(1)-C(12) distance, $1.43 \AA$, supports the hypothesis. Therefore it may not be surprising that the extra proton of the acid chloride was found at the $\mathrm{N}(2)$ position rather than at the other $\mathrm{N}$ atoms of the molecule. The $\mathrm{C}-\mathrm{S}$ bond length of $1.67 \AA$ agrees well with that in related compounds. The value is intermediate between a $\mathrm{C}-\mathrm{S}$ single-bond distance of $1.82 \AA$ and the double-bond value of $1.56 \AA$ (Sutton, 1965).

$\mathrm{C}(11)$ points away from $\mathrm{N}(1)[\mathrm{C}(4)-\mathrm{C}(10)-\mathrm{C}(5)$ $\left.126.0(9)^{\circ}, C(10)-C(4)-C(11) 125.3(9)^{\circ}\right]$ due to the steric hindrance between the bulky methyl and amino groups. The isoquinoline chromophore is approximately planar. $\mathrm{C}(12)$ lies in the plane; however, $\mathrm{N}(1)$ and $\mathrm{C}(11)$ deviate from it by -0.28 (1) and $0.23(1) \AA$ respectively, due to the steric interactions mentioned above.

\footnotetext{
* Lists of structure factors, anisotropic thermal parameters for the heavier atoms, $\mathrm{H}$-atom coordinates and Table 3 have been deposited with the British Library Lending Division as Supplementary Publication No. SUP 39041 (8 pp.). Copies may be obtained through The Executive Secretary, International Union of Crystallography, 5 Abbey Square, Chester CH $12 \mathrm{HU}$, England.

† Table 3 (deposited) contains biological activity and an extensive structure comparison (bond lengths, angles, torsion angles and dihedral angles between the chromophore and the side-chain planes) of:

ATSC: acetone thiosemicarbazone (Palenik, Rendle \& Carter, 1974).

4FPT: 4-pyridinecarbaldehyde thiosemicarbazone (Restivo \& Palenik, 1970).

5HP: 5-hydroxy-2-pyridinecarbaldehyde thiosemicarbazone (Palenik, Rendle \& Carter, 1974).

4MPT: 4-morpholino-2-pyridinecarbaldehyde thiosemicarbazone (Brown \& Agrawal, 1978).

4PPT: 4-phenyl-2-pyridinecarbaldehyde thiosemicarbazone (Brown \& Agrawal, 1977).

MAIQ: 5-amino-4-methyl-1-isoquinolinecarbaldehyde thiosemicarbazone (this work).

$\mathrm{Ni}^{11}(\mathrm{IQ})_{2}$ : bis(1-isoquinolinecarbaldehyde thiosemicarbazonato)nickel(II) (Mathew \& Palenik, 1969).
}

The entire side chain is almost planar and bends away from the isoquinoline plane by $15^{\circ}$ (Fig. 1b). The non-planarity of the molecule may be the result of steric interactions between $\mathrm{N}(2)$ and $\mathrm{N}(3)$ and between $\mathrm{N}(3)$ and $\mathrm{N}(5)[\mathrm{N}(2) \cdots \mathrm{N}(3) 2.65 \AA$, $\mathrm{N}(3) \cdots \mathrm{N}(5) 2.59 \AA]$. These atoms cannot form intramolecular hydrogen bonds. Similar dihedral angles between the side-chain and heterocyclic-ring planes were also observed in other thiosemicarbazone compounds. The dihedral angle, bond lengths and angles and the torsion angles in the thiosemicarbazone side chain are compared in Table 3 (deposited) for an aliphatic thiosemicarbazone, aromatic thiosemicarbazones of structures similar to MAIQ with/without antitumour activity and a bis $\mathrm{Ni}^{\mathrm{II}}$ complex of IQ. There seems to be no significant correlation between these structural parameters and

Table 1. Unit-cell positional and thermal parameters with estimated standard deviations in parentheses

\begin{tabular}{lllll} 
& \multicolumn{1}{c}{$x$} & $y$ & \multicolumn{1}{c}{$z$} & $B_{\text {eq }}\left(\AA^{2}\right)$ \\
$\mathrm{Cl}$ & $0.5948(5)$ & $0.7439(3)$ & $0.1006(3)$ & $4.09(8)$ \\
$\mathrm{C}(1)$ & $0.665(1)$ & $0.4328(9)$ & $0.6157(9)$ & $2.3(3)$ \\
$\mathrm{N}(2)$ & $0.757(1)$ & $0.4186(7)$ & $0.5268(9)$ & $2.9(3)$ \\
$\mathrm{C}(3)$ & $0.799(1)$ & $0.492(1)$ & $0.459(1)$ & $3.1(3)$ \\
$\mathrm{C}(4)$ & $0.760(2)$ & $0.5846(9)$ & $0.481(1)$ & $2.7(3)$ \\
$\mathrm{C}(5)$ & $0.623(2)$ & $0.7033(9)$ & $0.606(1)$ & $3.1(3)$ \\
$\mathrm{C}(6)$ & $0.513(2)$ & $0.711(1)$ & $0.683(1)$ & $4.6(4)$ \\
$\mathrm{C}(7)$ & $0.453(2)$ & $0.634(1)$ & $0.744(1)$ & $5.2(4)$ \\
$\mathrm{C}(8)$ & $0.509(2)$ & $0.543(1)$ & $0.727(1)$ & $3.7(3)$ \\
$\mathrm{C}(9)$ & $0.614(1)$ & $0.5286(8)$ & $0.638(1)$ & $2.5(3)$ \\
$\mathrm{C}(10)$ & $0.669(1)$ & $0.6072(9)$ & $0.572(1)$ & $2.4(3)$ \\
$\mathrm{C}(11)$ & $0.811(2)$ & $0.6552(9)$ & $0.394(1)$ & $4.1(4)$ \\
$\mathrm{N}(1)$ & $0.687(1)$ & $0.7840(7)$ & $0.554(1)$ & $4.3(3)$ \\
$\mathrm{C}(12)$ & $0.623(2)$ & $0.3477(9)$ & $0.674(1)$ & $3.1(3)$ \\
$\mathrm{N}(3)$ & $0.647(1)$ & $0.2655(7)$ & $0.6292(9)$ & $3.6(3)$ \\
$\mathrm{N}(4)$ & $0.593(1)$ & $0.1865(7)$ & $0.6822(9)$ & $3.2(2)$ \\
$\mathrm{N}(5)$ & $0.681(1)$ & $0.0970(8)$ & $0.5410(9)$ & $4.7(3)$ \\
$\mathrm{C}(13)$ & $0.604(2)$ & $0.0984(9)$ & $0.630(1)$ & $3.4(3)$ \\
$\mathrm{S}$ & $0.5135(5)$ & $0.0048(3)$ & $0.6885(3)$ & $4.65(9)$ \\
& & & &
\end{tabular}

Table 2. Bond lengths $(\AA)$ and angles $\left(^{\circ}\right)$ with estimated standard deviations in parentheses

$\begin{array}{llll}\mathrm{C}(1)-\mathrm{N}(2) & 1.36(1) & \mathrm{C}(6)-\mathrm{C}(7) & 1.40(1) \\ \mathrm{C}(1)-\mathrm{C}(9) & 1.43(1) & \mathrm{C}(7)-\mathrm{C}(8) & 1.37(1) \\ \mathrm{C}(1)-\mathrm{C}(12) & 1.43(1) & \mathrm{C}(8)-\mathrm{C}(9) & 1.43(1) \\ \mathrm{N}(2)-\mathrm{C}(3) & 1.36(1) & \mathrm{C}(9)-\mathrm{C}(10) & 1.44(1) \\ \mathrm{C}(3)-\mathrm{C}(4) & 1.36(1) & \mathrm{C}(12)-\mathrm{N}(3) & 1.28(1) \\ \mathrm{C}(4)-\mathrm{C}(10) & 1.40(1) & \mathrm{N}(3)-\mathrm{N}(4) & 1.36(1) \\ \mathrm{C}(4)-\mathrm{C}(11) & 1.51(1) & \mathrm{N}(4)-\mathrm{C}(13) & 1.38(1) \\ \mathrm{C}(5)-\mathrm{C}(6) & 1.34(1) & \mathrm{N}(5)-\mathrm{C}(13) & 1.28(1) \\ \mathrm{C}(5)-\mathrm{N}(1) & 1.41(1) & \mathrm{C}(13)-\mathrm{S} & 1.67(1) \\ \mathrm{C}(5)-\mathrm{C}(10) & 1.46(1) & & \end{array}$

\begin{tabular}{|c|c|c|c|}
\hline $\mathrm{N}(2)-\mathrm{C}(1)-\mathrm{C}(9)$ & $117.9(8)$ & $C(7)-C(8)-C(9)$ & $117.6(9)$ \\
\hline $\mathrm{N}(2)-\mathrm{C}(1)-\mathrm{C}(12)$ & $115.2(8)$ & $\mathrm{C}(1)-\mathrm{C}(9)-\mathrm{C}(8)$ & $118.1(8)$ \\
\hline $\mathrm{C}(9)-\mathrm{C}(1)-\mathrm{C}(12)$ & $126.8(8)$ & $C(1)-C(9)-C(10)$ & $119.9(8)$ \\
\hline $\mathrm{C}(1)-\mathrm{N}(2)-\mathrm{C}(3)$ & $122 \cdot 3(7)$ & $\mathrm{C}(8)-\mathrm{C}(9)-\mathrm{C}(10)$ & $122.0(8)$ \\
\hline$N(2)-C(3)-C(4)$ & $121.8(8)$ & $C(4)-C(10)-C(5)$ & $126.0(9)$ \\
\hline$C(3)-C(4)-C(10)$ & $120 \cdot 3(9)$ & $C(4)-C(10)-C(9)$ & $117.6(8)$ \\
\hline$C(3)-C(4)-C(11)$ & $114.3(9)$ & $C(5)-C(10)-C(9)$ & $116.4(8)$ \\
\hline$C(10)-C(4)-C(11)$ & $125.3(9)$ & $C(1)-C(12)-N(3)$ & $119.3(8)$ \\
\hline$N(1)-C(5)-C(6)$ & $122.3(9)$ & $\mathrm{C}(12)-\mathrm{N}(3)-\mathrm{N}(4)$ & $117.6(8)$ \\
\hline $\mathrm{N}(1)-\mathrm{C}(5)-\mathrm{C}(10)$ & $119.7(8)$ & $\mathrm{N}(3)-\mathrm{N}(4)-\mathrm{C}(13)$ & $118.3(7)$ \\
\hline$C(6)-C(5)-C(10)$ & $118.0(9)$ & $\mathrm{N}(4)-\mathrm{C}(13)-\mathrm{N}(5)$ & $116 \cdot 2(8)$ \\
\hline$C(5)-C(6)-C(7)$ & $124.8(9)$ & $N(4)-C(13)-S$ & $117.4(7)$ \\
\hline$C(6)-C(7)-C(8)$ & $120 \cdot 1(9)$ & $\mathrm{N}(5)-\mathrm{C}(13)-\mathrm{S}$ & $126.4(8)$ \\
\hline
\end{tabular}




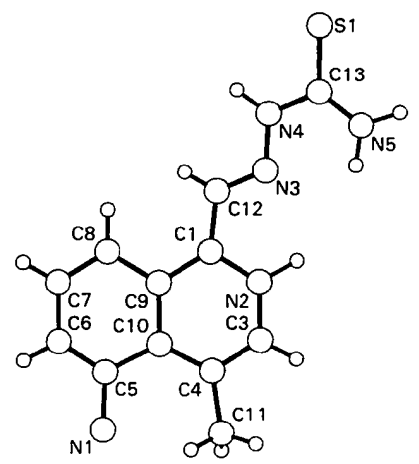

(a)

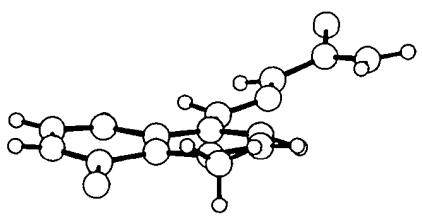

(b)

Fig. 1. (a) Plan and (b) side views of MAIQ. The amino $\mathrm{H}$ atoms were not located.

biological activity. A tridentate ligand seems to be required for the inhibition of RDR (Palenik, Rendle \& Carter, 1974), but the virtually zero activity of 4PPT* and the high activity of 4MPT cannot be explained. One notable structural difference is that 4PPT is highly planar. Substitution at positions 4 and 5 of IQ does not seem to affect the metal-complex formation.

All the side-chain conformations are trans about $\mathrm{N}(3)-\mathrm{N}(4)$ and $\mathrm{S}$ trans to N(3). 5HP, 4MPT and 4PPT molecules have to undergo two $180^{\circ}$ rotations about $\mathrm{C}(13)-\mathrm{N}(4)$ and $\mathrm{C}(1)-\mathrm{C}(12)$ to permit tridentate coordination to a metal ion, whereas MAIQ requires only one $180^{\circ}$ rotation. This is due to the fact that steric interaction between the $\mathrm{N}(3)$ and $\mathrm{H}(\mathrm{C} 8)$ inhibits the other conformation where $\mathrm{N}(2)$ is trans to $\mathrm{N}(3)$. The rotation about these bonds requires more energy when the thiosemicarbazone chains are more delocalized. In this sense, MAIQ seems to be a promising tridentate ligand, hence a hopeful antitumour drug.

\footnotetext{
* For abbreviations, see previous footnote.
}

Most of the thiosemicarbazones form intermolecular hydrogen bonds by way of $\mathrm{N}-\mathrm{H} \ldots \mathrm{S}$ interactions. The present compound is an acid chloride and the hydrogen bonding involves not sulphur but the chloride ion $\left[\mathrm{Cl} \cdots \mathrm{H}-\mathrm{N}\left(2^{\mathrm{l}}\right)=3.16 \AA, \quad \mathrm{Cl} \cdots \mathrm{H}-\mathrm{N}\left(4^{\mathrm{il}}\right)=3.26 \AA\right.$, $\mathrm{Cl} \cdots \mathrm{H}-\mathrm{N}\left(5^{i}\right)=3 \cdot 30 \AA$; (i) $\frac{1}{2}-x, y+\frac{1}{2}, \frac{1}{2}-z$, (ii) $1-x$, $1-y, 1-z]$.

We are grateful to the Cancer Research Campaign for support. MAIQ was a gift from the Drug Synthesis and Chemistry Branch, Division of Treatment, National Cancer Institute.

\section{References}

Agrawal, K. C., Booth, B. A., DeNuzzo, S. M. \& SArtorelli, A. C. (1976). J. Med. Chem. 19, 1209-1214.

Agrawal, K. C., Mooney, P. D. \& Sartorelli, A. C. (1976). J. Med. Chem. 19, 970-972.

Agrawal, K. C., Mooney, P. D., Schenkman, J. B., Denk, H., Moore, E. C. \& SARtorelli, A. C. (1975). Pharmacologist, 17, 201.

Agrawal, K. C. \& Sartorelli, A. C. (1975). Handbook of Experimental Pharmacology, Vol. 38, Part II, edited by A. C. SARTORELLI \& D. G. JoHNS, pp. 793-807. Berlin: Springer.

Brown, J. N. \& Agrawal, K. C. (1977). Acta Cryst. B33, 980-984.

Brown, J. N. \& Agrawal, K. C. (1978). Acta Cryyst. B34, 1002-1005.

Cutbush, S. D., Neidle, S. \& Wilman, D. E. V. (1983). Acta Cryst. C 39, 353-354.

French, F. A., Blanz, E. J. JR, Shaddix, S. C. \& Brockman, R. W. (1974). J. Med. Chem. 17, 172-181.

FRENZ, B. A. (1980). Enraf-Nonius Structure Determination Packages. Enraf-Nonius, Delft, Holland.

International Tables for X-ray Crystallography (1974). Vol. IV. Birmingham: Kynoch Press.

Main, P., Fiske, S. J., Hull, S. E., Lessinger, L., Germain, G., DEClerCQ, J.-P. \& WoOlfson, M. M. (1980). MULTAN80. A System of Computer Programs for the Automatic Solution of Crystal Structures from X-ray Diffraction Data. Univs. of York, England, and Louvain, Belgium.

Mathew, M. \& Palenik, G. J. (1969). J. Am. Chem. Soc. 19, 6310-6314.

Mooney, P. D., Booth, B. A., Moore, E. C., Agrawal, K. C. \& SARTORELli, A. C. (1974). J. Med. Chem. 17, 1145-1151.

Palenik, G. J., Rendle, D. F. \& CarTer, W. S. (1974). Acta Cryst. B30, 2390-2395.

Restivo, R. \& PaleniK, G. J. (1970). Acta Cryst. B36, 1397-1402.

Sartorelli, A. C., Agrawal, K. C. \& Moore, E. C. (1971). Biochem. Pharmacol. 20, 3119-3123.

SutTon, L. E. (1965). Tables of Interatomic Distances and Configuration in Molecules and Ions. Supplement. London: The Chemical Society.

Walker, N. \& Stuart, D. (1983). Acta Cryst. A34, 158-166. 